\title{
Systemic co-morbidities as a barrier to uptake of cataract surgery in Ibadan, Nigeria
}

\author{
A.S. Aina ${ }^{1}$, A. Ogundipe ${ }^{2}$, O.O. Ayorinde ${ }^{2}$ \\ ${ }^{1}$ Ophthalmology Unit, Department of Surgery, Bowen \\ University Teaching Hospital Ogbomoso, Oyo State, \\ Nigeria \\ ${ }^{2}$ Department of Ophthalmology, University College \\ Hospital, Ibadan, Oyo State, Nigeria
}

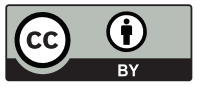
International License

Received: 2020-06-01

Accepted: 2020-06-17

UDC: 618.1

\section{$J$ Clin Med Kaz 2020; 4(58):41-44}

Corresponding Author: Dr. A.S. Aina, Ophthalmology Unit, Department of Surgery, Bowen University Teaching Hospital Ogbomoso, Oyo State, Nigeria.

Tel.: +2348033907271

E-mail: solarhema2013@yahoo.com
Abstract

Background: Barriers to uptake of cataract surgery in a developing country like Nigeria are numerous, most researches focus on patient related factor like financial constraint however this study aims to assess the systemic co-morbidities that act as a barrier to uptake of cataract surgery at University College Hospital Ibadan, Oyo-State, Nigeria so that measures can be put in place to minimize this effect and thereby increase cataract surgery uptake in the centre.

Results: Three hundred and eighty-eight cataract patients participated in the study. The mean age of the patients was $66.6 \pm 11.2$ years with a range of 40 to 90 years. More than half $(66.2 \%)$ of the study participants had systemic comorbidities. Poorly controlled systemic hypertension is the most common cause of systemic co-morbidities that constitute significant barrier to uptake of cataract surgery.

Conclusion: There is a need for good and close collaboration between the physicians and the ophthalmologists so as to make management of cataract patients with systemic co-morbidities easier and more efficient at the Eye Outreach Clinic of University College Hospital, Ibadan.

Key words: systemic co-morbidities, barrier, cataract surgery

\section{ИБАДАНДА, НИГЕРИЯДА КАТАРАКТА ХИРУРГИЯСЫН ЕНГІЗУГЕ КЕДЕРГІ РЕТІНДЕ ЖУЙЕЛІК ЖАНАМА АУРУЛАР}

А.С. Аина ${ }^{1}$, А. Огундипе ${ }^{2}$, О.О. Айоринде ${ }^{2}$

Радиациялық онкология бөлімшесі, Медициналық ғылымдар университеті, Ыстамбұл оқу-зерттеу ауруханасы, Ыстамбұл, Түркия

\section{ТҰЖЫРЫМДАМА}

Мақсаты: Нигерия сияқты дамушы елде катаракта хирургиясын енгізуге кедергілер көп, олардың көпшілігінде қаржылық қиындықтар сияқты пациенттерге байланысты факторларға назар аударылады, бірақ бұл зерттеу катарактты хирургияны енгізуге кедергі болатын жүйелік ауруды бағалауға бағытталған. Университеттік колледж ауруханасы, Ибадан, Ойо штаты, Нигерия, бұл әсерді азайтуға және осылайша орталықта катаракта хирургиясының көлемін ұлғайтуға бағытталған қадамдар жасалады.

Нәтижелері: Зерттеуге катаракта бар 388 науқас қатысты. Науқастардың орташа жасы 40-тан 90 жасқа дейін 66,6士11,2 жасты құрады. Зерттеуге қатысқандардың жартысынан көбінде $(66,2 \%)$ жүйелі жанама аурулар бар. Нашар басқарылатын жүйелік гипертензия катаракта хирургиясын енгізуге айтарлықтай кедергі болып табылатын жүйелік жанама аурулардың ең көп таралған себебі болып табылады.

Қорытынды: Ибадан Университеттік колледж ауруханасы жанындағы Eye Outreach Clinic клиникада жүйелі ауруы бар катарактасы бар науқастарын емдеуді жеңілдету және жақсарту үшін дәрігерлер мен офртальмологтардың арасында жақсы және тығыз ынтымақтастық қажет.

Негізгі сөздер: жүйелі жанама аурулар, кедергі, катаракта хирургиясы

\section{СИСТЕМНЫЕ СОПУТСТВУЮЩИЕ ЗАБОЛЕВАНИЯ КАК БАРЬЕР ДЛЯ ВНЕДРЕНИЯ ХИРУРГИИ КАТАРАКТЫ В ИБАДАНЕ, НИГЕРИЯ}

А.С. Аина' ${ }^{1}$ А. Огундипе ${ }^{2}$, О.О. Айоринде

'Отделение офтальмологии, Отдел хирургии, Университетская клиника Боуэн, Огбомосо, штат Ойо, Нигерия

${ }^{2}$ Отделение офтальмологии, Больница Университетского колледжа, Ибадан, штат Ойо, Нигерия

\section{PEЗЮME}

Цель: Барьеры для внедрения хирургии катаракты в развивающейся стране, такой как Нигерия, многочисленны, большинство исследований сосредоточено на связанных с пациентом факторах, таких как финансовые ограничения, однако данное исследование направлено на оценку системных сопутствующих заболеваний, которые действуют как барьер для внедрения операции по удалению катаракты в больнице Университетского колледжа, Ибадан, штат Ойо, Нигерия, с тем чтобы можно было принять меры для минимизации этого эффекта и тем самым увеличить охват хирургии катаракты в центре.

Результаты: В исследовании приняли участие 388 пациентов с катарактой. Средний возраст пациентов составил 66,6士11,2 года в диапазоне от 40 до 90 лет. Более половины $(66,2 \%)$ участников исследования имели системные сопутствующие заболевания. Плохо контролируемая системная гипертензия является наиболее распространенной причиной системных сопутствующих заболеваний, которые представляют собой значительный барьер для внедрения операции по удалению катаракты.

Заключение: Существует необходимость в хорошем и тесном сотрудничестве между врачами и офтальмологами, чтобы облегчить и повысить эффективность лечения пациентов с катарактой с системными сопутствующими заболеваниями в клинике Еуе Оитеасһ Сlinic при больнице Университетского колледжа, Ибадан.

Ключевые слова: системные сопутствующие заболевания, барьер, хирургия катаракты 


\section{Introduction}

Cataract is the leading cause of blindness globally and this presents an enormous challenge in terms of magnitude, functional disability, poor self-esteem, high economic loss, and social burden $[1,2]$. It is estimated that over $90 \%$ of blind people in the world live in low- and middle-income countries [3]. This is predominantly a consequence of limited access to eye care especially in poor settings attributable to non-availability of ophthalmic services in these regions [3].

Barriers to uptake of cataract surgery in low- and middleincome countries include lack of awareness of an existing eye care facility, poor surgical outcome, cost of surgery, cultural beliefs, distance from service and lack of an escort [3]. Several other studies [1,4-9] also reported cost and lack of awareness as the most frequent barriers to cataract surgery uptake. Some of the strategies designed to overcome these barriers include establishment of eye outreach clinics and eye camps, using media campaigns, mobilization of community health workers and subsidizing or totally sponsoring cataract surgical services [3]. However, evidence has shown that even when cataract surgical services are available and patients are willing to take up these services, some barriers such as 'patient's medical problem', 'long doctor's appointment', 'immature cataract', and 'hospital not ready' still prevent the uptake of cataract surgery in these patients [5].

Patient's medical problem is an important factor to consider in planning for cataract surgery because presence of uncontrolled systemic co-morbidities had been associated with increase of peri-operative complications [10,11]. These complications include retrobulbar hemorrhage, expulsive choroidal haemorrhage, posterior capsular rent, posterior capsular opacity, intra-operative hyphaema, delayed wound healing, severe post-operative inflammation and endophthalmitis $[12,13]$. Avoidance of these complications is likely to promote good cataract surgical outcome, increase cataract surgical uptake and thereby reducing the burden of blindness from cataract. For these reasons a 'Cataract surgery protocol' was given in VISION 2020 e-resource [14] and 'International Council of Ophthalmologist (ICO) clinical guideline' on management of cataract in patients with systemic co-morbidities [15]. These protocol and guideline state that Cataract Surgery should not be performed in people that cannot safely undergo surgery because of uncontrolled systemic co-morbidities and should be referred to physicians for control before undergoing the procedure [15].

Barriers to uptake of cataract surgery are similar in different regions of the world. In the Pakistan National Blindness and Visual Impairment Survey, cost was overwhelmingly the commonest barrier to uptake of cataract surgery $(76.1 \%)$, followed by lack of knowledge of the condition (11.5\%) [9]. In a multi-country study done in Bangladesh, Kenya and Philippines the most frequently reported barriers in all three countries were "unaware of cataract" (37\% in Bangladesh, 36\% in Kenya and $24 \%$ in the Philippines) and "cost" (38\%, 31\% and $32 \%$ in Bangladesh, Kenya and the Philippines, respectively) [4]. However in a study done in Osun state by Kolawole et al [1] "lack of awareness about cataract surgical service" (30.4\%) was the commonest barrier to uptake of cataract surgery while others include "no need for surgery" (17.6\%), cost (14.6\%), fear $(10.2 \%)$, "waiting for cataract to mature" $(8.8 \%)$, and "surgical services not available" (5.8\%). In a study done by Bekibele et al [5] in Ibadan, Nigeria apart from 'cost' being a major barrier as documented in other studies, 'untreated medical problems' were also found to be a significant barrier $(29.0 \%)$ to uptake of cataract surgery. Hence this study aim to assess the systemic comorbidities that acts as a barrier to uptake of cataract surgery in patients attending the eye outreach clinic of University College Hospital, Ibadan, Oyo State, Nigeria so that measures can be put in place to minimize this effect and thereby increase cataract surgery uptake in the centre.

\section{Material and methods}

This study was a descriptive cross-sectional study conducted among cataracts patients attending the Eye Outreach Clinic. Consecutive recruitment of all new cataract patients that met the inclusion criteria during the study period was done. Patients less than 40 years and/or with any other ocular co-morbidity causing visual impairment were excluded from the study. Informed consent was obtained. Semi-structured questionnaire was used to obtain socio-demographic data and medical history from study participants. Detailed ocular and systemic examinations were carried out. Patients with poorly controlled systemic co-morbidity were counseled and their cataract surgery was postponed. They were then referred to the physicians who will send them back for cataract surgery when certified fit. The time cataract surgery was done for all these patients were recorded and then categorized. Respondents that had their cataract surgery done within six days of presentation were said to have 'prompt cataract surgery' done while those between seven days and six weeks of presentation were said to have experienced 'delayed cataract surgery'. While those yet to have cataract surgery done after six weeks of initial presentation were said to have had a 'barrier in uptake of cataract Surgery'. Ethical approval was obtained from the University of Ibadan / University College Hospital institutional ethical committee. The study was carried out in line with the declaration of Helsinki for studies on human subjects.

\section{Results}

Three hundred and eighty-eight cataract patients were recruited into the study. The mean age of the patients was $66.6 \pm 11.2$ years with a range of 40 to 90 years. The peak age range of the patients was 70 to 79 years. There were $190(49 \%)$ males and $198(51 \%)$ females with male to female ratio of $1: 1$. Majority (41.0\%) were traders, $138(35.5 \%)$ of the respondents did not have formal education and $294(75.8 \%)$ were married. The average monthly income of majority $(84.5 \%)$ was more than $\$ 15,000$ (\$41.7) as shown in Table 1. Table 1 Socio-economic factors of the 388 cataract

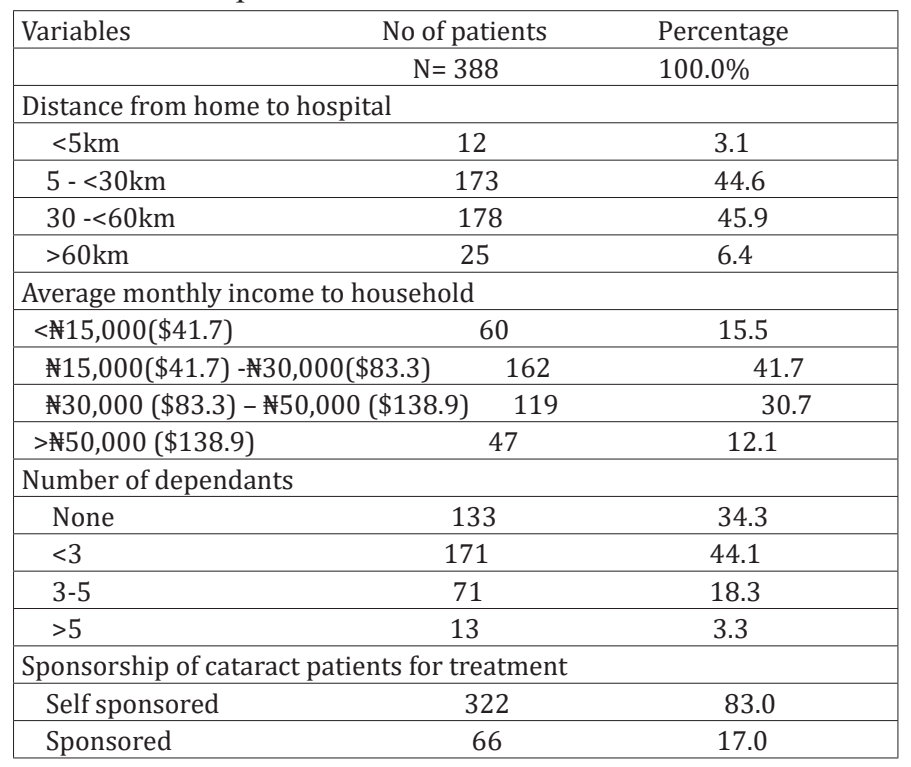


More than half $(66.2 \%)$ of the study participants had systemic co-morbidities. Systemic hypertension (48.1\%) was the most common systemic co-morbidity among the participants as shown in Table 2 .

Table 2 Distribution of systemic co-morbidities among the 388 study participants

\begin{tabular}{|l|l|l|l|}
\hline Co-morbidity & $\begin{array}{l}\text { Number of } \\
\text { Patients }(\%)\end{array}$ & $\begin{array}{l}\text { Controlled } \\
\text { Co-morbidity } \\
(\%)\end{array}$ & $\begin{array}{l}\text { Uncontrolled } \\
\text { Co-morbidity } \\
(\%)\end{array}$ \\
\hline Hypertension & $187^{*}(48.1 \%)$ & $83(21.4 \%)$ & $104(26.8 \%)$ \\
\hline Diabetes Mellitus & $38 *(9.8 \%)$ & $27(7.0 \%)$ & $11(2.8 \%)$ \\
\hline Respiratory Disease & $32(8.2 \%)$ & $23(5.9 \%)$ & $9(2.3 \%)$ \\
\hline
\end{tabular}

* five respondents had a combination of hypertension and diabetes

Among the 388 study participants, 226 (58.2\%) had prompt (within 7 days), 70 (18.1\%) had delayed (between 8 42 days) cataract surgery while $92(23.7 \%)$ were yet to have cataract surgery done after six weeks as shown in Figure 1.

Figure 1 - Level of uptake of cataract surgeries among cataract patients

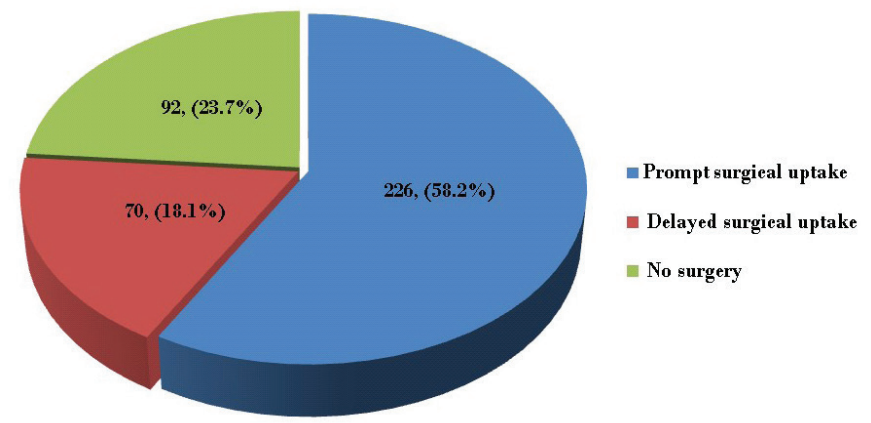

Reason for the delayed cataract surgery was mainly poorly controlled systemic hypertension 47 (67.2\%) patients. Other reasons are 'Patients no more financially ready' 12 (17.1\%), 'Poorly Controlled Diabetics Mellitus' 8 (11.4\%) and 'Unresolved cough' 3 (4.3\%).

Figure 2 - Barriers to uptake of cataract surgery

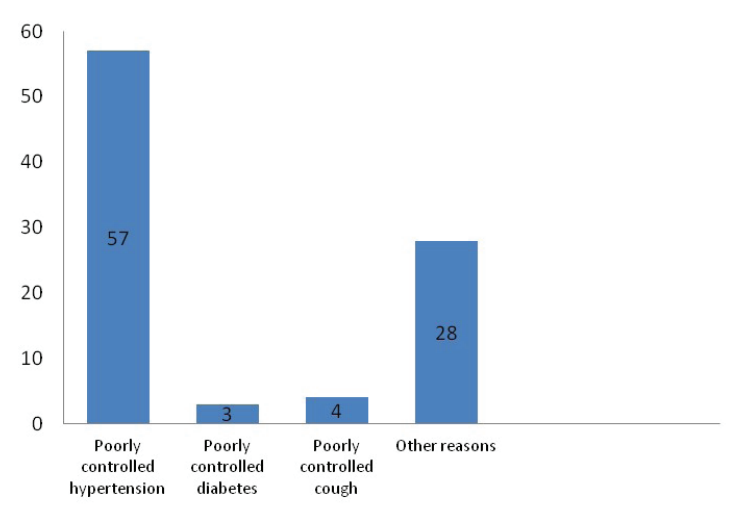

At the end of the study period, 92 (23.7\%) cataract patients never had cataract surgery done. Reasons for not having cataract surgery done were shown in Figure 2. Poorly controlled systemic hypertension in $57(62.0 \%)$ patients was the most common barrier to uptake of cataract surgery.

\section{Discussion}

Uncontrolled systemic hypertension is the commonest systemic co-morbidity causing a barrier to uptake of cataract surgery among the study participants. The prevalence of systemic hypertension among the cataract patients was $48.1 \%$ which was lower compared to that found in a study done by Pharm et al [16] in Sydney in which the prevalence of systemic hypertension in cataract patients was higher $(56 \%)$. This may be due to the fact that the age range of the population studied in Sydney was higher (60 years and above) compared to this study in which 40 years and above was studied. However, other studies done in India (20.59\%) [11] and Saudi-Arabia (30.5\%) [17] gave lower prevalence which may be because the patients in the Indian study were initially screened at an eye camp before being referred to the study centre so some individuals with uncontrolled systemic hypertension might not have been referred. Diabetes mellitus was present in $9.8 \%$ of the participants which was higher than the prevalence in a study done by Behera et al [11] in India $(5.9 \%)$. However the prevalence in Saudi-Arabia [17] and Sydney [16] were $34.6 \%$ and $27.5 \%$ respectively. Respiratory disease was present in $8.2 \%$ while $2.3 \%$ had active cough at presentation which was similar to the findings of Morice [18] in Europe (3-40\%) but in a population based study done by Desalu et al [19] in Ilorin, Nigeria he found a prevalence of 1.1\%, 1.7\% and $3.8 \%$ for chronic, subacute and acute cough respectively. All the respondents with active cough in this study had history of chronic cough which implies that it was likely to be an exacerbation of the existing respiratory problem hence cataract patients with history of chronic cough should be well assessed prior to uptake of cataract surgery.

Less than a quarter $(21.4 \%)$ of the study participants had good control of their systemic hypertension which was lower than the findings in Ibadan, Nigeria [20] and the United States [21] where $29 \%$ and $31 \%$ of the population studied had their systemic hypertension controlled respectively. This might be because the study in Ibadan was done in a hypertensive clinic so many of the patients might have being on antihypertensive medications. Twenty seven $(7.0 \%)$ out of the 38 patients with diabetic mellitus (DM) had good control of their DM.

More than half $(58.2 \%)$ of the cataract patients had prompt uptake of cataract surgery which indicates the effectiveness of the eye outreach unit which aims to make prompt cataract surgery services available to patients when they present. One hundred and sixty-two (41.8\%) of the study participants could not have cataract surgery done immediately they presented to the hospital mainly because of uncontrolled systemic comorbidities. However $70(18.1 \%)$ of the patients had their cataract surgery done within 6 weeks (range: 8 - 42 days) of treatment while $92(23.7 \%)$ are yet to have cataract surgery done at six weeks despite being on treatment for the systemic co-morbidities. Poorly controlled systemic hypertension was the most common systemic co-morbidites $(62.0 \%)$ preventing the uptake of cataract surgery in these patients. This was similar to the findings in a study done in Brazil [22] where high blood pressure accounted for $88.9 \%$ of the cancellation of cataract surgery among their patients. Also Bekibele et al [5] in Ibadan found out that untreated medical condition (systemic hypertension and diabetes mellitus) accounted for $29 \%$ of barrier to access cataract surgery in their study population. The persistently uncontrolled systemic co-morbidities in this study might be due to poor compliance with medications which is attributable to either lack of proper understanding on why they need to be compliant with their medications or lack of money to procure their medications as prescribed by the physician. 
Systemic co-morbidities, mainly systemic hypertension but occasionally diabetes mellitus and cough constitute significant barriers to uptake of cataract surgery at the Eye Outreach Clinic of University College Hospital, Ibadan. A closer attention to prevention, early diagnosis and appropriate management of these medical conditions, empowerment of the populace and improved service provision will contribute to increased uptake of cataract surgical services at the Eye Outreach Clinic of University College Hospital, Ibadan. There should be good interaction between the physicians and the ophthalmologists so as to make management of cataract patients with systemic comorbidities easier and more efficient. Also, an efficient system of follow-up on referred cataract patients for control of systemic co-morbidities should be established so that they can still have the intended cataract surgery done.

Disclosures: There is no conflict of interest for all authors.

\section{References}

1. Kolawole OU, Ashaye AO, Mahmoud AO, Adeoti CO. Cataract blindness in Osun state, Nigeria: results of a survey. Middle East Afr J Ophthalmol. 2012; 19(4):364-371. https://doi.org/10.4103/0974-9233.102741

2. Bastawrous A, Dean WH, Sherwin JC. Blindness and visual impairment due to age-related cataract in sub-Saharan Africa: a systematic review of recent population-based studies. Br JOphthalmol.2013;97(10):1237-1243.https://doi.org/10.1136/bjophthalmol-2013-303135

3. Blanchet K, Gordon I, Gilbert CE, Wormald R, Awan H. How to Achieve Universal Coverage of Cataract Surgical Services in Developing Countries: Lessons from Systematic Reviews of Other Services. Ophthalmic Epidemiol. 2012; 19(6):329-339. https://doi.org/10.3109 /09286586.2012.717674

4. Syed A, Polack S, Eusebio C, Mathenge W, Wadud Z, Mamunur AK, et al. Predictors of attendance and barriers to cataract surgery in Kenya, Bangladesh and the Philippines. Disabil Rehabil. 2013; 35(19):1660-1667. https://doi.org/10.3109/09638288.2012.748843

5. Bekibele CO, Murthy GV, Barriers to cataract surgery of persons screened at camps in Ibadan, Nigeria. Afr J Med Med Sci. 2012; 41(3):257-264.

6. Mpyet C, Dineen BP, Solomon AW. Cataract surgical coverage and barriers to uptake of cataract surgery in leprosy villages of north eastern Nigeria. Br J Ophthalmol. 2005; 89(8):936-938. https://doi.org/10.1136/bjo.2004.062455

7. Oluleye T. Cataract blindness and barriers to cataract surgical intervention in three rural communities of Oyo State, Nigeria. Niger $J$ Med. 2004; 13(2):156-160.

8. Osaguona VB, Ukponmwan CU, Kayoma DH, Okojie OH. Ocular health status of patients seen at the screening centre of the University of Benin Teaching Hospital, Benin city, Nigeria-A preliminary report. Journal of Medicine and Biomedical Research. 2012; 11(2):4450 .

9. Jadoon Z, Shah SP, Bourne R, Dineen B, Khan MA, Gilbert CE. et al. Cataract prevalence, cataract surgical coverage and barriers to uptake of cataract surgical services in Pakistan: the Pakistan National Blindness and Visual Impairment Survey. Br J Ophthalmol. 2007; 91(10):1269-1273. https://doi.org/10.1136/bjo.2006.106914

10. Lundström M, Barry P, Henry Y, Rosen P, Stenevi U. Visual outcome of cataract surgery; Study from the European Registry of Quality Outcomes for Cataract and Refractive Surgery. J Cataract Refract Surg. 2013; 39(5):673-679. https://doi.org/10.1016/j.jcrs.2012.11.026

11. Behera BK, Satish K, Jena SK, Hussain M, Samal S. Prevalence Of Hypertension And Diabetes Mellitus Among People Seeking Cataract Surgery In Rural South India. The Internet Journal of Epidemiology. 2012; 10(2). https://doi.org/10.5580/2af6

12. Nouvellon E, Cuvillon P, Ripart J. Regional Anesthesia and Eye Surgery. Anesthesiology. 2010; 113(5):1236-1242. https://doi. org/10.1097/ALN.0b013e3181f7a78e

13. Pacella E, Pacella F, Troisi F, Dell'Edera D, Tuchetti P, Lenzi T, et al. Efficacy and safety of $0.5 \%$ levobupivacaine versus $0.5 \%$ bupivacaine for peribulbar anesthesia. Clin Ophthalmol. 2013; 7:927-932. https://doi.org/10.2147/OPTH.S43553

14. VISION 2020 e-resource Cataract Surgery Protocol. http://admin.iapbafrica.co.za/Uploads/ResourceFiles/126/Cataract-Surg-Protocols. pdf

15. International Council of Ophthalmologist (ICO) International Clinical Guideline; Cataract (Initial and follow-up evaluation). http:// www.icoph.org/resources/resources_detail/77/ICO-International-Clinical-Guideline-Cataract-Initial-and-follow-up-evaluation-html

16. Pham TQ, Wang JJ, Rochtchina E, Maloof A, Mitchell P. Systemic and ocular comorbidity of cataract surgical patients in a western Sydney public hospital. Clin Experiment Ophthalmol. 2004; 32(4):383-387. https://doi.org/10.1111/j.1442-9071.2004.00842.x

17. Al-Orainy AN, Omar SAA, Jahan S. Co-Morbidity of Age Related Cataract Surgical Patients in a Tertiary Care Hospital in Saudi Arabia. Saudi Journal of Ophthalmology. 2007; 21(2):105-109.

18. Morice A. The diagnosis and management of chronic cough. Eur Respir J. 2004; 24(3):481-492. https://doi.org/10.1183/09031936.04. 00027804

19. Desalu OO, Salami AK, Fawibe AE. Prevalence of cough among adults in an urban community in Nigeria. West Afr J Med. 2011; 30(5):337-341.

20. Yusuff KB, Balogun O. Physicians' prescribing of anti-hypertensive combinations in a tertiary care setting in southwestern Nigeria. $J$ Pharm Pharm Sci. 2005; 8(2):235-242.

21. Wang Y, Wang QJ. The prevalence of prehypertension and hypertension among US adults according to the new joint national committee guidelines: new challenges of the old problem. Arch Intern Med. 2004; 164(19):2126-2134. https://doi.org/10.1001/archinte.164.19.2126

22. Lira RPC, Covolo GA, Monsanto AR, José NK, Arieta CEL. Influence of preoperative testing on cancellation of ambulatory cataract surgery in adults. Annals of ophthalmology. 2002; 34(3):203-205. https://doi.org/10.1007/s12009-002-0024-6

How to cite this article: A.S. Aina, A. Ogundipe, O.O. Ayorinde. Systemic co-morbidities as a barrier to uptake of cataract surgery in Ibadan, Nigeria. J Clin Med Kaz. 2020; 4(58):41-44 